\title{
CAMINHOS E DESCAMINHOS ENTRE O PRINCÍPIO DA RESPONSABILIDADE E O ÜBERMENSCH
}

\author{
Paths and astray patbs between The Imperative of Responsibility and The Übermensch
}

\author{
José Jaime da Silva \\ Mestrando em População, Território \\ e Estatísticas Públicas da Escola \\ Nacional de Ciências Estatísticas - \\ ENCE/IBGE.
}

RESUMO: O objetivo deste trabalho é mostrar os pontos de encontro entre o princípio da responsabilidade (Hans Jonas) e o conceito de Übermensch (Nietzsche). O impacto da Revolução Industrial com aumento das riquezas e o rápido avanço técnico deu esperanças de que a técnica traria um progresso contínuo. Nessa euforia surge Nietzsche criticando esse modo de ver a realidade, denunciando as falsas ideias da modernidade. A crítica nietzschiana à modernidade se dá na denúncia que ele faz dos ideais da modernidade: a razão, progresso técnico-científico, sociedade justa e livre, etc. No séc. XX o mundo ocidental sofreu com as falhas de seus projetos ideológicos na política, na economia, no trabalho, etc. As promessas de mundo melhor ficaram por terra depois de catástrofes no séc. XX que desembocam em uma crise ambiental que é vista por pesquisadores como grande ameaça à existência humana. Hans Jonas propõe que o agir humano seja de tal forma que a permanência de uma autêntica vida humana na terra seja garantida. Jonas deixa de lado uma ética metafísica e abre espaço para uma ética na imanência. O Übermensch de Nietzsche que afirma a vida pode ser entendido como seguidor de seus instintos e ligado a natureza, logo um homem sensível aos problemas ambientais. Um desencontro entre os conceitos podem ser as ideias de bem e mal que estão no princípio da responsabilidade, um encontro seria a transformação do medo em coragem que conduz a ação que superaria a crise ambiental. Ambos os autores não chegaram necessariamente no mesmo lugar por caminhos diferentes.

PALAVRAS-CHAVE: Responsabilidade; Übermensch; meio-ambiente. 
Os primeiros filósofos da era moderna (século XVI) desenvolveram a compreensão de que o homem poderia conhecer rigorosamente a natureza através da ciência moderna e com a aplicação deste conhecimento controlar os movimentos daquela em proveito da vida humana e do melhoramento da organização entre os homens. A tese de Bacon de que "saber é poder" mostra bem o clima desta época. À frente destes ideais está uma maneira inédita (empírica, compartimentada, quantificada) de conhecer a realidade.

Se Galileu afirma que "a natureza está escrita em linguagem matemática" (pensamento simplificador e quantificador), e Descartes nos propõe a razão para a sua conquista em nome do ego cogito, Bacon elabora um método para dominar a natureza, "obrigá-la a dar respostas", fazendo-a "serviçal, escravizando-a" (Bacon). Diante disso tudo, o antigo conceito da Terra como mãe nutriente cai literalmente "por terra". O olhar sobre a vida torna-se rígido e mecanicista. ${ }^{1}$

Segundo Pelizzoli a partir da Revolução Cientifica a razão adquire a capacidade de reduzir o mundo em várias categorias e essa mesma racionalidade daria a possibilidade de conhecer as leis que regem a natureza. Assim a ciência moderna poderia dar ao homem a capacidade de reproduzir, modificar e controlar os fenômenos da natureza em via de enriquecer materialmente o ser humano.

No século XIX o impacto da Revolução Industrial no mundo ocidental com o enriquecimento material e o rápido aprimoramento técnico alimentou a esperança de que as descobertas da ciência e os avanços da técnica trariam um progresso contínuo para a vida humana na terra ${ }^{2}$. Em meio a essa euforia por progresso surge Nietzsche criticando esse modo esperançoso de olhar para a realidade de sua época, denunciando as falsas ideias da modernidade e desmentindo as estimativas para o futuro.

Um tema pertinente na filosofia dele, apontado por Giacoia, é que "o domínio do homem sobre a natureza traz consigo a possibilidade, senão a inexorabilidade, da superação do homem"3. Ao passar pelo processo de civilizar-se, este vai de encontro, primeiro, com sua própria natureza, age contra suas pulsões, naquilo que Nietzsche chama de moral dos escravos. Em segundo lugar esse homem domesticado começa a criar, através de ideologias, instituições, educação, ética, um mundo que também vai de encontro com o mundo ao seu redor. O conceito de natureza que estamos usando é o "princípio de vida e de movimento de todas as coisas existentes". Esta se apresenta cheia de movimentos e pulsões que o homem moderno ignora em

${ }^{1}$ PELIZZOLI M. L., Correntes da ética ambiental. Petrópolis: Vozes 2002, p. 10.

2 MATOS, Junot Cornélio. Críticas Nietzcheanas à Modernidade. Revista Impulso, Piracicaba, v. 12, n. 28, 2001 , p. $136-7$.

3 GIACOIA JUNIOR, Oswaldo. Sonhos e pesadelos da razão esclarecida. Revista o que nos faz pensar, Rio de Janeiro, n.

18, setembro de 2004 p. $103-4$

4ABBAGNANO, Nicola. Dicionário de Filosofia. São Paulo. Martins Fontes. 2007, p. 814. 
nome de uma proposição metafísica de que o homem deveria dominar a natureza e que esta deveria servi-lo.

A crítica nietzschiana à modernidade se dá na denúncia que ele faz dos ideais da modernidade: a razão como guia da humanidade, progresso técnico-científico resolvendo todos os problemas, esperança de uma sociedade justa e livre, ideia de progresso continuo da economia, etc. A valorização destas utopias e a crença no poder de resolver as dores humanas traz um grande mal para o tipo humano. Segundo Nietzsche estes conceitos tem um lado nefasto, pois são falsos e negam a vida tornando o homem um "animal de rebanho". Ao torná-lo essa "criatura domesticada" a força que o levaria ao seu crescimento e aperfeiçoamento também é neutralizada. Para ele o mundo ocidental está se tornando niilista, ou seja, um mundo aonde todos os valores supremos vão sendo desvalorizados.

Durante o século XX o mundo ocidental sofreu com as falhas de seus projetos ideológicos na política, na economia, no trabalho, na ciência, na vida quotidiana, etc. As promessas de um mundo melhor ficaram por terra depois de duas grandes guerras, crises econômicas, sistemas políticos totalitários, epidemias, fome, desigualdade social e por fim uma crise ambiental que é vista por pesquisadores como grande ameaça à existência futura da humanidade. Ao longo do século passado as promessas nascidas na modernidade pareciam se tornar cada vez menos possíveis de serem concretizadas. Podemos perceber a importância da crítica nietzschiana a ideia de progresso dada à impossibilidade de manutenção de exploração de recursos naturais que o cenário contemporâneo expõe bem como um determinado nível de acerto dos apontamentos nietzschianos. A crise contemporânea do meio ambiente pode ser entendida como uma crise ética ou do movimento de desvalorização de todos os valores supremos (niilismo) que o mundo ocidental vive, segundo Nietzsche, logo podemos perceber a importância do pensamento deste para essa crise.

Hans Jonas parte da mudança que a técnica tem na modernidade. Se na antiguidade a técnica tinha um papel se subordinação à natureza e procurava basear-se nela em seu desenvolvimento, na era moderna a técnica aparece como uma ferramenta de domínio do homem sobre a natureza. Assim o sucesso da técnica moderna aparece como um perigo. Este perigo vem do poder de destruição da própria natureza. Surge então a questão de uma ética que consiga lidar com as novas condições do homem na terra. Jonas aponta que as morais tradicionais (aristotélica e kantiana) não levam em consideração a técnica e ao principio da responsabilidade é cabido sua superação. Diante do possível perigo dos avanços da técnica, devese assumir uma posição de responsabilidade; esta posição é levada pelo medo ${ }^{5}$. No entanto, Jonas

\footnotetext{
${ }^{5}$ LIMA, M. de. O princípio responsabilidade de Hans Jonas e a crítica de Karl-Otto Apel. Seara Filosófica, 2010.
} 
admite a transformação do medo em coragem para ser responsável pela garantia da vida no futuro.

Dado o exposto o objetivo deste trabalho é mostrar os pontos de encontro e desencontro entre o princípio da responsabilidade (Hans Jonas) e o conceito de Übermensch (Nietzsche). Pretende-se mostrar a visão de Nietzsche da relação do homem com a natureza e sua crítica. Em seguida expor os apontamentos de Hans Jonas sobre a relação do homem com a natureza e por fim apontar os caminhos e descaminhos entre os dois autores.

\section{Nietzsche e a relação do homem com a natureza.}

Partindo de um trecho do aforismo 9 da segunda dissertação da obra Genealogia da Moral de Nietzsche, podemos discutir a moral ocidental e como se deu o distanciamento do homem do mundo que o circunda, fazendo com que o sonho de criar um mundo melhor passando pela exploração da natureza se erigiu. Uma forma de tratar a natureza surgiu junto com os ideais modernos.

... pois precisamente as coisas opostas às que hoje veneramos tiveram durante muito tempo a consciência do seu lado, e Deus como seu guardião. Híbris é hoje nossa atitude para com a natureza, nossa violentação da natureza com ajuda das máquinas e da tão irrefletida inventividade dos engenheiros e técnicos; híbris é nossa atitude para com Deus, quero dizer, para com uma presumível aranha de propósito e moralidade por trás da grande tela e teia da causalidade... ${ }^{6}$ (grifo nosso)

O termo híbris é grego e designa um ato de ultraje que deve ser punido ${ }^{7}$. Essa forma de tratar a natureza vem de uma moral estabelecida por um determinado tipo psicológico. Nietzsche diz que ao determinar como o homem deveria ser, ou seja, ao tentar mudar a natureza do homem foi preciso negar o mundo. Então, foi se criando um novo mundo onde não existem paixões (os instintos são negados) ${ }^{8}$. Para melhorar o homem com essa moral, foi preciso torná-lo manso, ou seja, "castrar" seus instintos primitivos. Logo, quando esse homem tentou melhorar o mundo ao seu redor foi preciso extrair a rudeza que existe na natureza.

Essa extração pode ser entendida como violentação (ou excessiva exploração dos recursos naturais) que os avanços tecnológicos possibilitaram à civilização moderna. Isto

\footnotetext{
${ }^{6}$ NIETZSCHE, Friedrich. Genealogia da Moral. Trad. Paulo César de Souza. São Paulo: Companhia das Letras, 2009a, p. 94-5.

7 Vale reproduzir nota de Paulo César de Souza sobre o termo: “Híbris': palavra com que os antigos gregos designavam todo comportamento arbitrário, arrogante, desrespeitador dos direitos do próximo e das normas da comunidade. No sentido mais geral, aquele em que é empregada por Nietzsche, era - é - a violação das leis divinas ou naturais". A nota se encontra na página 149 de Genealogia da Moral, edição da Companhia das Letras, 2009.

${ }^{8}$ NIETZSCHE, Friedrich. Crepúsculo dos Ídolos. Trad. Paulo César de Souza. São Paulo: Companhia das Letras, 2006, p. 37.
} 
desencadeou uma crise ambiental que pode ser entendida como as previsões catastróficas de sobre a finitude dos recursos naturais e das consequências do aquecimento global para a vida de todos os animais no planeta.

Segundo Giacoia essa crise parece fazer com que o sonho moderno se torne um pesadelo ${ }^{9}$, mesmo assim abre espaço para um tema da filosofia de Nietzsche como proposta de superação do atual estado. Dado o inegável poder técnico-científico de autodeterminação cabe ao homem, e não a forças metafísicas ou científicas, a tarefa de autodeterminação. As ideias nietzschianas conduzem para a transvalorização dos valores como forma de superação do "último homem"10 que o mundo ocidental cultivou. Na Genealogia da Moral ele buscou revelar a origem de nossos valores morais e suas consequências no mundo moderno, no entanto pode-se extrair uma leitura onde a superação do homem (ou de seus valores morais) levaria à superação da crise ambiental.

Uma questão que pode ser posta como hipótese é se a genealogia da moral feita por Nietzsche aponta, entre outras coisas, os pressupostos filosóficos da relação ética do homem com a natureza que engendraram a atual crise ambiental, além de repensar esta relação em vias de apontar, seguindo o pensamento de Nietzsche, formas de superação desta ética e, logo, do problema ambiental.

É interessante salientar que o problema ambiental pode ser entendido como um problema político, logo vale observar os apontamentos de Nietzsche sobre a política. Segundo a leitura que Delbó faz sobre uma possível filosofia política em Nietzsche, pode-se entender que este faz uma crítica à política em sua época que se faz à tendência da criação de estados democráticos. A democracia seria uma herança cristã, logo levaria a moralidade cristã em seus fundamentos. Então o estado democrático faria com que os valores do tipo fraco (moral dos escravos) prevalecessem, levando adiante apenas os seres mais debilitados (ou incapacitados). Neste cenário o que Nietzsche chama de "acasos felizes" da humanidade correria risco de não existirem. Estes acasos são os tipos que tem valores mais nobres e fortes (moral dos senhores). Para Nietzsche a política deveria elaborar a cultura e melhorar a organização social visando o engrandecimento e autoelaboração da humanidade ${ }^{11}$. No entanto suas críticas se justificam pela forma como os valores são instituídos, como Delbó diz:

É porque a tarefa de instituir os valores a cada coisa ocorre a partir da perspectiva típica de um mercador e atinge as funções do estadista, dos povos e dos partidos, que Nietzsche mantém seus inúmeros ataques à política democrática. As preocupações do mercador são, para ele, nocivas para a

\footnotetext{
${ }^{9}$ GIACOIA JUNIOR, Oswaldo. Sonhos e pesadelos da rąão esclarecida. p. 103.

${ }^{10}$ Expressão utilizada no livro "Assim Falou Zaratustra" para designar o niilista.

${ }^{11}$ DELBÓ, Adriana. Nietzssche: sobre alguns problemas morais da democracia moderna. Cadernos Nietzsche, São Paulo, n. 32, maio de 2013, p. 149-154.
} 
política e para todas as outras elaborações da vida de um povo. E é por ver toda a cultura envolta por estimativas de valor reduzidas à oferta e à demanda, que os vínculos entre política e cultura na modernidade, são para, ele perniciosos. ${ }^{12}$

Neste caso o modo de valorar o mundo através de um fator econômico (oferta e demanda) seria nocivo tanto para a humanidade e para a natureza que o homem está inserido, dado que a "perspectiva de mercador" tenta mudar a natureza para que esta o sirva economicamente.

$\mathrm{Na}$ Genealogia da Moral, Nietzsche procura mostrar o desenvolvimento da história de nossa moral. Dado que a moral é um conjunto de valore que guiam a comportamento das pessoas no mundo ele entende a moral de outra forma. Para Nietzsche a moral é uma maneira de avaliar o mundo que deu origem aos conceitos de bem e mal, por exemplo, que deveriam ser seguidos. $\mathrm{O}$ filósofo faz uma reconstituição de como se deu a criação e instituição dos valores morais para o homem, ou seja, como o homem deu o cunho de "bem" e "mal" para tudo aquilo que o cerca e para o comportamento que ele pode assumir. Bem como investiga a partir de qual cenário político, social e cultural o homem criou para si esses valores. Nietzsche fez essa investigação se apoiando tanto em hipóteses como em proposições etimológicas. Toda a filosofia de Nietzsche parece girar em torno do conflito existente entre duas morais que ele chama de "moral dos senhores" e "moral dos escravos". Para ele a origem do sentido dos termos "bom" e "ruim" foi dada por aqueles que primeiro as utilizaram, ou seja, a nobreza ou aristocracia. E o termo bom os representavam e o seu modo de viver não havendo associação como a ideia de utilidade. O termo "ruim" era apenas o complemento usado por essa classe aristocrata para se distinguir daqueles que não pertenciam à mesma classe, ou seja, o homem simples, o "povo".

A partir desta origem Nietzsche explica como surgiu outra dupla de termos ("bom" e "mal") que veio a entrar em conflito com a primeira. Havia uma aristocracia que era formada tanto por uma classe política como por uma classe sacerdotal. Então houve uma transição dessa nobreza política para uma nobreza sacerdotal onde os senhores e aristocratas também eram sacerdotes. Segundo Nietzsche a partir desta transição foi o povo judeu que fez uma inversão dos valores nobres 13 . Para este povo o "mal" é o "bom" dos antigos aristocratas e o "bom" é a negação do "bom" dos aristocratas, ou seja, não ser como o tipo aristocrata. Nietzsche chama esses dois tipos de moral por várias nomenclaturas (fraco/forte, ave de rapina/ovelha, senhor/escravo, doente/sadio, moralista/imoralista, etc.), no entanto iremos adotar os termos "moral dos senhores" e "moral dos escravos". Segundo Nietzsche o surgimento dessa moral dos

12 Ibidem, p. 162.

${ }^{13}$ NIETZSCHE, Friedrich. Para Além do Bem e do Mal. Trad. Alex Marins. São Paulo: Martin Claret, 2001a, p. 110. 
escravos se dá devido a incapacidade do homem simples (escravo) se tornar forte como o tipo aristocrata (senhor). Assim essa segunda forma de valorar o mundo nasce desse tipo comum, ou escravos, que a partir de sua incapacidade de ser como os primeiros tipos (os senhores) invertem os valores daqueles criando outra dupla "bom e mal" onde esse valor negativo, "o mal", é exatamente designado pelas atitudes da moral dos senhores e o "bom" são os que não são daquele jeito, ou seja, os escravos. Esses escravos têm valores reativos, pois nascem da reação que têm ao se deparar com a outra moral ${ }^{14}$.

Segundo Nietzsche por toda a história da humanidade houve uma guerra entre essas duas morais, a mais árdua e longa guerra já travada. E saiu desta uma vencedora, mas antes vale destacar uma metáfora que Nietzsche usa para descrever como esses tipos se viam:

Que as ovelhas tenham rancor às grandes aves de rapina não surpreende: mas não é motivo para censurar às aves de rapina o fato de pegarem as ovelhinhas. E se as ovelhas dizem entre si: 'essas aves de rapina são más; e quem for o menos possível ave de rapina, e sim o seu oposto, ovelha - este não deveria ser bom?', não há o que objetar a esse modo de erigir um ideal, exceto talvez que as aves de rapina assistirão a isso com ar zombeteiro, e dirão para si mesmas: 'nós nada temos contra essas boas ovelhas, pelo contrário, nós as amamos: nada mais delicioso do que uma tenra ovelhinha'.15

O desenvolvimento desta luta milenar deu-se com a maneira como a moral dos senhores foi envenenada pela moral dos escravos e fez com que estes últimos predominassem.

[...] não é de espantar que os afetos entranhados que ardem ocultos, ódio e vingança, tirem proveito dessa crença, e no fundo não sustentem com fervor maior outra crença senão a de que o forte é livre para ser fraco, e a ave de rapina livre para ser ovelha - assim adquirem o direito de imputar à ave de rapina o fato de ser o que é... ${ }^{16}$ (grifo do autor)

A crença que ele está falando é na liberdade, pois se acreditando que se é livre para ser forte (ou fraco) e mostrando que ser forte é mal e que é melhor ser fraco se envenena a moral dos senhores. Aquela moral envenenou e transformou a "ave de rapina" em "ovelha", para usar um termo de Nietzsche, fazendo com que esta veja com misericórdia a "ovelhinha oprimida" e acredite que sua postura é uma escolha fazendo que no fim aquela se torne também uma "ovelha". Nietzsche aponta que a moral dos escravos dominou o mundo ocidental desta maneira e trouxe consequências negativas para o futuro da humanidade.

A partir do domínio desta última sobre mundo ocidental Nietzsche faz sua crítica à metafísica, ao modelo socrático-platônico, a moralidade cristã, ao antropocentrismo, a crença no poder da ciência, a ideia de progresso, a modernidade e ao homem moderno que herda todos os

\footnotetext{
${ }^{14}$ NIETZSCHE, Friedrich. Genealogia da Moral. Prólogo e primeira dissertação 2009a.

${ }^{15}$ NIETZSCHE, Friedrich. Genealogia da Moral. p.32.

16 Ibidem, p.33.
} 
aspectos desta "moral escrava". Para ele esses ideais modernos nascem do domínio da "moral dos fracos" no mundo ocidental. Pode parecer que Nietzsche está criticando todos, ele faz isso, por acreditar que todas as esferas da atividade humana estão contaminadas por essa "doença" que vem do modo de valorar o mundo voltado para a fraqueza, embora existam outras maneiras de valorar o mundo. Como ele diz:

A moral é hoje na Europa uma moral de animal de rebanho. Portanto, na nossa opinião, apenas uma espécie particular de moral humana, ao lado ou antes ou depois da qual são possíveis ou deveriam ser possíveis muitas outras morais, principalmente morais superiores. ${ }^{17}$ (grifos do autor)

Como essa moral se espalhou pelo mundo ocidental, Nietzsche percebe que há uma decadência da cultura, que o mundo está ficando niilista, que o animal homem está ficando mais pobre, que há uma negação da vida e entre todos esses "sintomas" está o homem moderno. Para ele a vida pode ser entendida como um conjunto de energias, pulsões e instintos naturais em constante luta e que a moral pode afirmar a vida, fazendo-a crescer e expandindo a capacidade de agir da humanidade, ou nega a vida, fazendo-a pequena e reduzindo a capacidade humana. Segundo Nietzsche, este homem também está "doente", e "cansado da vida"; por isso que ele nega a vida, ou seja, não consegue lidar com sua incapacidade.

Tal relação do homem com a natureza, supomos ter surgido da tradição da modernidade filosófica. $\mathrm{Na}$ modernidade surgem alguns ideais como a liberdade (livre-arbítrio), a crença no progresso capitalista trazendo riqueza para todos, a esperança de que a ciência resolveria os problemas humanos, etc. Deste último surge a ideia de dominar a natureza em proveito da vida humana criando uma relação sujeito/objeto. Com Descartes o ser humano é separado da natureza (o sujeito do objeto), o mundo é reduzido em partes para melhor se explicar a vida. Galileu percebe uma linguagem matemática na natureza e começa a fazer experimentos e descobertas sobre o funcionamento da mesma. Bacon introduz o método indutivo que pode descobrir as leis da natureza. Pode-se perceber a necessidade de dominar e controlar a natureza que os conceitos destes pensadores traziam ${ }^{18}$.

Nietzsche tem uma visão do cosmos como regido por forças plurais, e a vida nasce de uma dessas forças que se manifesta de forma orgânica. No entanto, ele aponta que existem forças ativas e forças reativas. Estas últimas teriam guiado o nascimento da moral dos fracos a partir de um olhar ressentido sobre o mundo. Nasce daí uma maneira do homem se relacionar com a natureza que implica em exploração dos recursos da natureza. É possível entender que a valorização de um mundo perfeito e a tentativa de dominar e modificar a natureza vem do

\footnotetext{
${ }^{17}$ NIETZSCHE, Friedrich. Para Além do Bem e do Mal. p. 116.

18 PELIZZOLI, M. L. Correntes da ética ambiental. p. 7-11.
} 
domínio da moral dos escravos. Com a incapacidade de lidar com o mundo como ele é estes tentariam torná-lo um lugar livre das dores e que proporcionasse conforto material para todas as pessoas. Assim uma reação é produzida da incapacidade de lidar com a natureza como ela se apresenta, criando assim um ideal de natureza que serve ao homem. Para Nietzsche estes ideais modernos são falsos e entende a modernidade "como uma época histórica cuja principal característica é a negação da vida, pela imposição de valores morais que reduzem o homem a mero animal gregário" ${ }^{\prime 19}$. Os valores morais que ele está falando fazem parte da moral dos escravos que no lugar de enriquecer o ser humano estariam empobrecendo-o.

A dominação dessa moral também é entendida como a desvalorização de todos os valores que ele chama de niilismo. Vale ressaltar o quê este termo vem a ser entendido na filosofia de Nietzsche. Segundo Deleuze o niilismo em Nietzsche tem dois significados. O primeiro é um niilismo negativo onde a vida é negada em nome de valores superiores como Deus, o bem, o verdadeiro. Neste caso o mundo é apresentado como mundo das aparências e este mundo é negado em nome do mundo-verdadeiro (o paraíso ou o mundo das ideias de Platão). O segundo é o niilismo reativo onde "o niilista nega Deus, o bem e até mesmo o verdadeiro, todas as formas do supra-verdadeiro" "20. Como Nietzsche diz no aforismo 125 de A Gaia Ciência:

'Para onde foi Deus?', gritou ele, 'já lhes direi! Nós o matamos - vocês e eu. Somos todos seus assassinos! Mas como fizemos isso? Como conseguimos beber inteiramente o mar? Quem nos deu a esponja para apagar o horizonte? Que fizemos nós, ao desatar a terra de seu sol? Para onde se move ela agora? Para onde nos movemos nós? Para longe de todos os sóis? Não caímos continuamente?21

A expressão "morte de Deus" pode ser entendida com o final da era moderna e de seus fundamentos como sugere Vattimo. Esse evento marcaria a entrada na pós-modernidade onde é revelada a insignificância dos ideais que fundaram a modernidade ${ }^{22}$. No entanto, o niilista ao negar os valores superiores e se voltar para a vida, ainda encontra uma vida negada e sem valor. Se antes a vida era negada em nome de valores suprassensíveis agora esses valores também são negados e resta ficar em um mundo cada vez mais sem valor; cada vez mais niilista. O homem reativo "coloca-se no lugar de Deus: não conhece mais valores superiores". Então outros valores surgem deste homem reativo ${ }^{23}$. Como Deleuze diz:

o homem reativo toma o lugar de Deus: a adaptação, a evolução, o progresso, a felicidade para todos, o bem da comunidade; o Homem-Deus, o homem moral,

\footnotetext{
${ }^{19}$ MATOS, Junot Cornélio. Críticas Nietz̧cheanas à Modernidade. p. 135.

${ }^{20}$ DELEUZE, Gilles. Nietzsche e a Filosofia. Trad. Ruth Joffily e Edmundo Fernandes Dias. Rio de Janeiro: Editora Rio, 1976, p. 69-70.

${ }^{21}$ NIETZSCHE, Friedrich. A gaia ciência. Trad. Paulo César de Souza. São Paulo: Companhia das Letras, 2001, p. 6465.

22 VATTIMO, Gianni. O fim da modernidade: niilismo e hermenêutica na cultura pós-moderna. Trad. Eduardo Brandão. $2^{\mathrm{a}}$ Ed. São Paulo: Martins Fontes, 2007 P. 169-174.

${ }^{23}$ DELEUZE, Gilles. Nietzsche e a Filosofia. p. 69-70.
} 
o homem verídico, o homem social. São esses os valores novos que nos são propostos em lugar dos valores superiores, são esses os personagens novos que nos são propostos em lugar de Deus ${ }^{24}$

Aquele homem (com H maiúsculo), que nega o mundo presente, está destruindo este mundo e, ao mesmo tempo, destruindo a si mesmo, para alimentar uma ideia de conforto material, ou um ideal de felicidade para todos, ou uma ideia de mundo melhor no futuro. O tipo fraco tinha que criar outro mundo onde pudesse se realizar por não ser capaz de se realizar neste mundo. Segundo Nietzsche o homem faz isto pela incapacidade de lidar com o mundo empírico que nos cerca e de lidar com os movimentos instintivos da natureza (inclusive de sua própria natureza). Pois a moral dos fracos tem que encontrar um culpado e puni-lo. Como afirma Marton:

Com Platão e o cristianismo, ocorreu a duplicação dos mundos - e passou-se a negar este em que nos achamos aqui e agora em nome de outro, essencial, imutável e eterno. Com a modernidade, procedeu-se à implosão do ser humano - e foi ele dividido em razão e paixões, intelecto e sentidos, consciência e instintos. ${ }^{25}$

Neste caso a tentativa de mudar a natureza é uma forma de dizer que há um erro no mundo e que este deve ser consertado, ou seja, esta tentativa deriva da moral dos escravos que nega este mundo em nome de outro, seja metafísico ou seja no futuro. Isso liga os apontamentos da genealogia nietzschiana a atual crise ambiental pela postura que temos diante da natureza.

Outro ponto que merece destaque é o entendimento de niilismo que Vattimo defende. Ele tenta mostrar como os conceitos de niilismo se aproximam em Heidegger e em Nietzsche. Para Heidegger o niilismo é a consumação do Ser no valor, que Vattimo entende como sendo o valor de troca. O Ser se perderia e/ou se transformaria neste tipo de valor. Pode ser coincidente com o conceito de niilismo de Nietzsche, pois este falou da desvalorização dos valores supremos, mas não dos valores "tout court" (ou seja, os valores pequenos); estes valores continuam e junto com eles o valor de troca. No que diz respeito às características da sociedade capitalista, Vattimo entende que a transformação de tudo em "valor de troca" no século XX mostra os últimos momentos de uma desumanização (consumação do nilismo) e que os esforços contra essa reificação foram ainda um niilismo reativo, pois buscava se reapropriar do sujeito e parar o domínio do objeto. Aquela experiência de mercantilização abre espaço para uma possível nova experiência humana ${ }^{26}$. Logo, podemos entender que a exploração da natureza que vem sendo praticada pelo capitalismo moderno se dá pela transformação da natureza em valor de troca, ou

\footnotetext{
24 Ibidem, p. 70.

${ }^{25}$ MARTON, Scarlett. Do dilaceramento do sujeito à plenitude dionisíaca. Cadernos Nietzsche, São Paulo, n. 25, maio de 2009 , p. 58.

${ }^{26}$ VATTIMO, Gianni. O fim da modernidade. p. 4-16.
} 
seja, se a exploração da natureza é uma negação do mundo como ele se apresenta, transformando-o em valor de troca, podemos entender isso como outra forma de niilismo.

Nietzsche estava lúcido de todos esses problemas modernos e abre espaço para a ideia de superação do homem e aponta para o Übermensch (super-homem). Para Nietzsche este homem (moderno) deve ser superado. Como ele expõe no livro "Assim Falou Zaratustra": "Exorto-vos, meus irmãos, a permanecer fiéis à terra e a não acreditar em quem vos fala de esperanças supraterrestres". E em seguida:

O homem é um rio turvo. E preciso ser um mar para, sem se toldar, receber um rio turvo. Pois bem; eu vos anuncio o Super-homem; é ele esse mar; nele se pode abismar o vosso grande menosprezo. ${ }^{27}$

Segundo Heber-Suffrin o Übermensch seria o homem de uma nova cultura e de uma nova moral que são animadas pela vontade de potência ${ }^{28}$. Em meio a estas ideias ele está mostrando a necessidade de o homem dar um novo sentido sobre a terra. Nietzsche está apontando tanto para a ideia de superação do homem e para a ideia de superação dos valores morais do homem moderno (no caso a superação da moral dos escravos); este super-homem (Übermensch) que afirma a vida pode ser entendido como seguidor e controlador de seus instintos, logo um homem sensível aos problemas do meio ambiente por aceitar e afirmar tanto seus instintos como a natureza ao seu redor. Logo, esse super-homem traria, assim, a possibilidade de superação da atual crise ambiental. Não apenas a crise ambiental, mas a consumação do niilismo também abre espaço para a superação do homem e da crise ambiental com a transvalorização dos valores.

\section{HANS JONAS E RELAÇÃO DO HOMEM COM A NATUREZA.}

Hans Jonas aponta para a necessidade de uma nova ética diante dos avanços da técnica. Para ele o poder de destruição da tecnologia exige do homem a responsabilidade de preservação da vida na terra. Assim ele enuncia o princípio da responsabilidade como um imperativo para agir "de modo que os efeitos da tua ação sejam compatíveis com a permanência de uma autêntica vida sobre a Terra". Ele entende que o homem faz parte de um todo (a natureza). O principio surge exatamente desta nova visão do homem como um ser inserido em um sistema maior e que depende deste sistema maior para continuar vivendo. Para Hans Jonas o fim da natureza é a vida, logo com o principio ficamos condenados a ser responsáveis.

\footnotetext{
${ }^{27}$ NIETZSCHE, Friedrich. Assim Falou Zaratustra. Trad. Alex Marins. São Paulo: Martin Claret, 2009b, p. 26.

${ }^{28}$ HÉBER-SUFFRIN, Pierre. O "Zaratustra” de Nietəsche. Rio de Janeiro: Jorge Zahar, 2003.
} 
Uma questão levantada sobre sua teoria é que de sentenças descritivas não se pode retirar sentenças prescritivas, seria uma falácia da natureza. Este problema se apresenta como não podendo estabelecer um valor moral a partir de um princípio determinado pela natureza. A ação moral tem que vir de uma norma e não de uma descrição. Como a natureza é apenas descritiva ela não pode determinar um principio moral. Se isto fosse possível a ação estaria sendo determinada fora do agente e assim o agente não seria livre. Então, Jonas não quer tirar a ética da ontologia, mas mostrar que a ética está contida na ontologia. Ele presa pela permanência de uma vida digna na terra ${ }^{29}$.

\section{CAMINHO E DESCAMINHOS.}

A proposta de Jonas é ampliar o campo de visão da ética, saindo de uma ética apenas humana e considerando a natureza. Assim o homem não é apenas preocupado com sua conduta, mas com os impactos da sua conduta na natureza, ou seja, responsável pela natureza em que habita. Uma solução que Jonas aponta para o problema da falácia da natureza é reafirmar que o homem pertence a natureza, mas sua moral continua centrada no homem; daí o termo "biologização do ser moral" 30. Neste ponto de considerar o homem como um ser a mais na natureza tanto Jonas como Nietzsche andam pelo mesmo caminho. A teoria das forças ${ }^{31}$ Nietzsche que chega a este entendimento.

Para além disto Jonas coloca dois argumentos contra a falacia naturalista. Primeiro que a responsabilidade é uma constatação ontológica (o ser é responsável) e segundo que o ser deve ser responsável por que o ser é (e não por que a natureza é). Para Jonas o ser "contem" a responsabilidade, então existe, (faz sentido) um "dever ser do ser" ${ }^{32}$.

Jonas fundamenta (ontologicamente) o Bem recusando os dualismos entre eles espírito e matéria. Assim como Nietzsche supera o entendimento de que o mundo é duplicado em mundo sensível e mundo racional, corpo e alma, etc. No entanto, a ideia de Bem na essência do ser não é compartilhada em Nietzsche. Não existe um bem em si que dê sentido ao mundo.

A responsabilidade vem do próprio ser. Se apresenta como um imperativo ontológico (a responsabilidade). A “sobrevivência real do ser" depende de observar o princípio da responsabilidade. A sobrevivência do ser no futuro que gera este imperativo ontológico. Jonas chega a uma imposição de cuidado (ou responsabilidade) do homem com a natureza que o

\footnotetext{
${ }^{29}$ LIMA, O princípio responsabilidade de Hans Jonas e a crítica de Karl-Otto Apel. Seara Filosófica, 2010.

${ }^{30}$ SGANZERLA, A. Biologização do ser moral em Hans Jonas. Revista de Filosofia: Aurora, v. 25, n. 36, p. 155-178, 2013.

31 Teoria de que o mundo é formado por forças plurais em constante conflito mutúo.

32 Ibidem.
} 
homem faz parte, mas partindo de uma visão um tanto metafísica. Nietzsche chegaria a um alémhomem sensível as questões de preservação da natureza, não pela metafísica, mas pelo conhecimento tanto ele quanto a natureza têm origem na mesma força e ambos tem a mesma vontade.

Jonas coloca que a liberdade é o resultado "teleológico" da natureza. Assim o homem é o ser responsável pela sua própria sobrevivência. Logo, para continuar sendo homem deve ser responsável. O princípio pede que se preserve a condição de existência da humanidade. Neste caso o homem é livre para escolher ser responsável. Dado que em seu desejo de progresso o homem coloca a existência futura em perigo. Jonas afirma que a vida é um fim que está na natureza e ao mesmo tempo um valor fundamental e a autoconservação é um fim em si mesmo para Jonas ${ }^{33}$. No entanto, a natureza não tem uma finalidade para Nietzsche, não existe uma ordenação moral no mundo que possa ser derivado para um sentido da conduta humana. As forças em conflito buscam apenas afirmar sua força (ou afirmar seu poder).

Para Nietzsche os fins são a indicação que uma vontade de poder (ou vontade de potência) dominou algo menos poderoso e inseriu uma função. Assim os fins não são dados tão pouco eternos. Assim o desenvolvimento de uma "coisa" pode ser uma sequência de novas interpretações e subjugamentos que recebe e não um progresso na direção de um fim ${ }^{34}$. No tocante as teorias evolucionistas que colocam como essência da vida a adaptação Nietzsche aponta que a essência da vida seria a vontade de potência e a adaptação apareceria apenas como uma atividade de segunda ordem. A força espontânea dessa vontade precede a "adaptação". Assim a ética da preservação - admitir que existe uma natureza e que o homem faz parte dela de Jonas se distancia na origem que levaria a uma possível harmonia na relação do homem com a natureza assim como no conceito de vida dos autores.

É necessário se perguntar se ambos os autores chegaram no mesmo lugar (conceito de homem ou conduta) por caminho nem sempre iguais? A resposta é negativa, pois o além-homem percebe que ele é parte da natureza e não tem uma finalidade, nem ele nem a natureza, mas uma constante promoção de encontros ou choques que ora são harmoniosos ora são conflituosos e em alguns casos fazem a vontade de potência se expressar (manifestar) positivamente (se expandindo) e outras vezes se manifesta negativamente (se contraindo). Não necessariamente que esta força se manifeste positivamente nos encontros harmoniosos e negativamente nos encontros conflituosos. Inclusive Nietzsche aponta para o aumento de vontade de potência no conflito ${ }^{35}$.

\footnotetext{
33 Ibidem.

${ }^{34}$ NIETZSCHE, Friedrich. Genealogia da Moral. Trad. Paulo César de Souza. São Paulo: Companhia das Letras, 2009a, p. 62.

${ }^{35}$ NIETZSCHE, Friedrich. Para Além do Bem e do Mal. São Paulo: Martin Claret, 2001ª.
} 
O sim à vida jonasiano leva a um bem em si. $\mathrm{O}$ bem em si seria um sentido novo na terra como afirma o Zaratustra? A resposta que pode ser colocada como hipótese é que o Zaratustra afirma uma atribuição de um novo sentido da terra na imanência e também no aqui/agora. Enquanto o princípio de preservar a vida que dá ao homem a responsabilidade seria uma troca da vida hoje, que está acontecendo, por uma no futuro (um futuro que nunca chega) que ameaça. Ou pelo menos, um pensar atual com a ameaça do futuro terrível como pano de fundo. Este futuro seria ainda transcendente e não imanente. Além do mais, quando Jonas aponta que devemos ter a responsabilidade de cuidar da continuidade da vida, ele está desviando do enfrentamento com a questão da finitude. Uma extrapolação desta fuga individual para a escala universal levaria a questão da finitude da humanidade. Nietzsche aponta que deveríamos dar boas vindas a morte (a finitude), mas para isto deveríamos ter consumado nossa vida em sua riqueza, ou seja, na expansão e expressão cada vez mais exuberante de uma luta e conquista por mais vontade de poder. 


\section{REFERÊNCIAS}

ABBAGnANO, N. Dicionário de Filosofia. São Paulo: Martins Fontes, 2007.

DELBÓ, A. Nietzsche: sobre alguns problemas morais da democracia moderna. Cadernos Nietzsche, v. 32, 2013.

DELEUZE, G. Nietzsche e a Filosofia. Rio de Janeiro: Editora Rio, 1976.

GIACOIA JUNIOR, O. Sonhos e pesadelos da razão esclarecida. Revista o que nos faz pensar, v. 18, 2004.

HÉBER-SUFFRIN, P. O “Zaratustra” de Nietzsche. Rio de Janeiro: Jorge Zahar, 2003.

LIMA, M. DE. O princípio responsabilidade de Hans Jonas e a crítica de Karl-Otto Apel. Seara Filosofica, 2010.

MARTON, S. Do dilaceramento do sujeito à plenitude dionisíaca. Cadernos Nietzsche, v. 25, p. 1-121, 2009.

MATOS, J. C. Críticas Nietzcheanas à Modernidade. Revista Impulso, v. 12, 2001.

NIETZSCHE, F. Para Além do Bem e do Mal. São Paulo: Martin Claret, 2001a.

NIETZSCHE, F. A gaia ciência. São Paulo: Companhia das Letras, 2001b.

NIETZSCHE, F. Crepúsculo dos Ídolos. São Paulo: Companhia das Letras, 2006.

NIETZSCHE, F. Genealogia da Moral. São Paulo: Companhia das Letras, 2009a.

NIETZSCHE, F. Assim Falou Zaratustra. São Paulo: Companhia das Letras, 2009b.

PELIZZOLI, M. L. Correntes da ética ambiental. Petrópolis: Vozes, 2002.

SGANZERLA, A. Biologização do ser moral em Hans Jonas. Revista de Filosofia: Aurora, v. 25, n. 36, p. 155-178, 2013.

VATTIMO, G. O fim da modernidade: niilismo e hermenêutica na cultura pós-moderna. São Paulo: Martins Fontes, 2007. 